So Close, So Far.

\title{
National Identity and Political Legitimacy in UAE-Oman Border Cities
}

\author{
Marc VALERI \\ University of Exeter
}

This manuscript is the version revised after peer-review and accepted for publication.

This manuscript has been published and is available in Geopolitics:

Date of publication: 26 December 2017

DOI: $10.1080 / 14650045.2017 .1410794$

Webpage: http://www.tandfonline.com/doi/full/10.1080/14650045.2017.1410794 


\section{Introduction}

Oman-United Arab Emirates border, Thursday 5 May 2016 early morning. As it has been the case for years on long weekends and holidays, endless queues of cars from Oman are waiting to cross the border in order to flock to Dubai for Isra' and Miraj break ${ }^{1}$ and enjoy attractions and entertainment that their country does not seem to offer. Major traffic congestions are taking place in the Omani city of al-Buraymi separated from the contiguous United Arab Emirates city of al-Ayn by the international border.

Many border cities are contiguous urban areas which have been 'dependent on the border for [their] existence' or even 'came into existence because of the border'. ${ }^{2}$ Usually once military outposts (Eilat/Aqaba, on the Israel-Jordan border ${ }^{3}$ ), they developed on either side of a long established border (Niagara Falls cities, on the Canada-USA border) after a border had been drawn (Tornio, on the Sweden-Finland border; ${ }^{4}$ cities on the Mexico-USA and ChinaRussia $^{5}$ borders). Furthermore, split-up cities which were partitioned after World War II, including in Central Europe (e.g. on the Germany-Poland border ${ }^{6}$ ), experienced some transfer of original population and relocation of a totally different one on an ethno-cultural basis due to the drawing of new borders. ${ }^{7}$

None of these applies to the case of al-Ayn/al-Buraymi, where the urban settlement long predates the border. These two cities existed as a unique oasis (known as al-Buraymi) comprised of nine small villages until the late 1950s, when agreements for the reciprocal recognition of territorial jurisdiction were signed by the Sultan of Oman and the Emir of Abu Dhabi, at the initiative of the British. Six villages, including Ayn al-Dhawahir (later known as al- 
Ayn) were deemed to pay tribute to the ruler of Abu Dhabi and the remaining three, including al-Buraymi itself, historically the oasis' largest village, were recognised loyal to Oman. When the sultanate of Oman and the federation of the United Arab Emirates (UAE) became independent from the British (in 1970 and 1971 respectively), this political division of the oasis was confirmed, but without physical borderline and border control materialising it other than on the maps until the beginning of the $21^{\text {st }}$ century. Individuals were used to cross regularly the border from one country to another, the two towns effectively working like one unit. It is in 2002 only that the UAE started to install a fence along its border with Oman, including in the al-Ayn/alBuraymi conurbation.

The political and economic trajectories of al-Ayn and al-Buraymi, whose populations reached 519,000 and 104,000 respectively in 2016 (see table 1), have been adversarial, epitomising the evolution of the relationship between the two countries. The common past and the 'notion of being one community with common interests and belonging together' ${ }^{8}$ have been present among inhabitants of al-Ayn and al-Buraymi since the independence, with the maintenance of close contacts (through family and marriage relations, and business activities) across the border. However the top-down political priorities of both national leaderships in the UAE and Oman have contributed to substantially re-define the perception of the border in these cities and the local populations' life and actions. In particular, the drawing of an international demarcation across the oasis has led to the sprouting of new dynamics resulting from the increasing divergence of trajectories of social and economic development. Because of these conflicting evolutions and the absence of like-mindedness and of 'intention to construct 
and maintain the common space or to reach common goals', ${ }^{9}$ al-Ayn and al-Buraymi cannot be regarded as a 'binational city' or even as 'twin cities'. ${ }^{10}$

While most studies on this oasis have concentrated on the pre-independence era, and in particular on the dispute over its control during the $1950 \mathrm{~s},{ }^{11}$ this paper chooses to focus instead on its evolution since the early 1970s. The study of these two border cities, sharing history but growing apart since the beginning of the $21^{\text {st }}$ century, provides a window onto unfolding patterns of the construction of political sovereignty and legitimacy in post-colonial states and the link between the building of national identity and the physical demarcation from the (br)other. Since the early 1970s and the accession of Oman and the United Arab Emirates to the independence, the building of both a state apparatus and a nation has lain at the heart of the political projects of the two rulers to assert their political legitimacy and control over their respective territory. This issue of the mutual relationship with the neighbour has been particularly crucial, given the tribal and ethnic proximity between inhabitants living across the new international boundary but also the two countries' shared modern history.

The paper, which is structured into two parts, shows that the opposed trajectories followed by the border cities of al-Ayn and al-Buraymi after the independence emulate the way how the United Arab Emirates and Oman have grown separately. The first part of the paper will highlight the slow process of mutual recognition between the two newly independent countries from the 1970 s to the beginning of the 2000s. While comparable state-building projects were implemented simultaneously in Abu Dhabi and Muscat, the trajectories of al-Ayn and alBuraymi started diverging significantly due to the contrasting role central authorities gave to these cities in respective state-building projects. This paper then shows in a second part that 
the question of the separation from the (br)other re-emerged at the beginning of the 2000s while both countries had to face domestic challenges calling into question the socio-political order established in the 1970s. This had a direct impact on the management of the border, since growing suspicions and mistrust in both capitals resulted in al-Ayn and al-Buraymi increasingly turning their back to each other. These processes have been accompanied by renewed questioning related to respective national identities, especially when dealing with the relation to the brother across the border.

\section{Twin post-independence nation-building projects but opposite}

\section{management of the borderlands}

Former President of the federation of the United Arab Emirates Sheikh Zayed Al Nahyan (r.1971-2004) and Sultan Qaboos of Oman (r.1970-...) accessed power in similar circumstances. They both overthrew the incumbent ruler - Zayed's brother and Qaboos's father - with the help of British advisers. Their respective room to maneuver with regard to the British were reduced to a minimum, as a result of the imperial policy that had been developed since the mid- $19^{\text {th }}$ century. The Gulf had become a place 'where time had stood still [...] frozen into the requirements of the pax Britannica ${ }^{12}$ and where political actors were isolated from the outside world and tributary to Britain alone. However this had started changing in the late 1950s, at the heyday of Arab nationalism, and the southern shore of the Gulf was not cut off from political convulsions anymore. In particular, the Dhofar region, in Southern Oman, was the theatre from the 1960s of an uprising against the authority of then Sultan of Oman Said bin Taymur (r. 1932- 
70). Gradually, this movement morphed into the Marxist-Leninist Popular Front for the Liberation of the Occupied Arabian Gulf (PFLOAG). In July 1970, when the uprising was about to spread to northern Oman, the British orchestrated the Sultan of Oman's overthrow by his son Qaboos. This coup enjoyed the support of the shah of Iran and the other Gulf rulers, most notably the ruler of Abu Dhabi, Zayed Al Nahyan, worried by potential revolutionary contagion from Dhofar to the rest of the Gulf. ${ }^{13}$ It is no surprise that Zayed provided a substantial financial help to the new Omani ruler during the Dhofar war, including the provision of a garrison for Sohar (Northern Oman) in 1974 to free Qaboos's troops for fighting the war in the South, ${ }^{14}$ which officially ended in 1975.

\section{Oman-UAE relations after the 1970s: 'Twin palm-trees on the same land'?}

This war proved decisive for both rulers, as it destroyed the most credible political alternative to their national leadership and helped them asserting their political control on the newly independent states by defining a new order for which they alone would hold the keys. To this end, in both cases, an ambitious policy of national unification was implemented, which has become the pivot of the regime's ideology. This policy has been based on the oil rent, a godsend which gave the capacity to implement a widespread redistribution game within the framework of an allocation state and which is reserved to nationals only. The public sphere became an inexhaustible tank of jobs open to all levels of skill, on territories characterised for several decades by emigration. The new civil servants, employed in the national army and police, the intelligence service, the ministries and governmental services, were all the less 
inclined to rise against the regime because they depend on it for their daily lives. Similarly, in both Abu Dhabi and Oman, a rewriting of identity frames of reference around the person of the ruler, identified in the new historiography with the contemporary welfare state and consequently with the country itself, was implemented. This political work on history has aimed at 'naturalising' the special pantheon-the contemporary regime, the welfare state, and the institution and person of the ruler, portrayed as the 'father of the nation' - which has been the basis for both regimes' legitimacies. However, bilateral relationships between the two rulers remained cool for a long period, despite - or, rather, because of - the intimacy of respective national-building projects and the two countries' shared modern history. ${ }^{15}$

While Muscat recognised the new UAE state in 1971, it refused to appoint an ambassador in Abu Dhabi on the basis that the relations between the two countries were so close historically that it was not even necessary to appoint an ambassador. In an interview in the 1970s, Sultan Qaboos explained: 'The brotherly relations between the two peoples are flourishing, for this has surpassed the diplomatic and routine and complex procedures. By this I mean: we are two brothers, you [the UAE] in your house and we in ours, but the two houses are next to each other. Do you really need a mediator? In my opinion, what affects you affects me automatically'. ${ }^{16}$ Even Dhofari revolutionaries from the PFLOAG and Arab nationalist opposition forces to the rulers of the UAE and Oman viewed the two 'as one national entity' and 'believed in the 'Natural Oman' idea, the unification of the Trucial States with Muscat and Oman'. ${ }^{17}$

Mutual relations deteriorated after the 1974 Jeddah agreement between the UAE and Saudi Arabia over the demarcation of the UAE-Saudi Arabia border. While Saudi Arabia officially 
dropped its claim on al-Buraymi oasis, ${ }^{18}$ Oman considered that the two other countries had reached agreement over a part of its territory. Armed clashes happened in December 1977 at the border, and many Omanis serving in the UAE army refused to fight against Omani troops. ${ }^{19}$ After more than a one year of negotiation, an agreement was signed in April 1979 to fix $10 \%$ of the total length of the Oman-UAE border. The Sultan of Oman then became aware that too much inflexibility would have made economic and social cooperation with the UAE, which was vital for Oman, more difficult.

The rulers of Oman and Abu Dhabi came closer personally during the 1980s; this move led to enhanced economic and security relations and to the first exchange of ambassadors in 1991. ${ }^{20}$ In April 1992 Oman and UAE citizens were granted permission to move across the border on an identity card instead of a passport. In May 1992, a joint UAE-Oman commission was then entrusted with examining the border issue. In 1993 an official from the Omani ministry of Foreign Affairs declared that 'Oman and the Emirates were twin palm-trees on the same land', ${ }^{21}$ while the Dubai daily al-Khaleej, at the beginning of the negotiations, had the headline: 'One nation, two states' ${ }^{22}$ In government newspapers and official statements, the relationship between the two countries became increasingly portrayed along terms referring to brotherhood. A final agreement on total delimitation was ratified by the rulers in Abu Dhabi on 22 June 2002. In a July 2002 interview, Sheikh Zayed expressed his deep satisfaction over the firm and distinguished fraternal relations between the two countries, which have further enhanced affinities of brotherhood, kinship and common history binding the peoples of both countries [...] He added that the UAE and Oman, by reaching that historic agreement [on the 
border], have presented an example that could be emulated in sorting out border issues between friendly and sisterly countries'. ${ }^{23}$

For al-Ayn and al-Buraymi, these post-independence decades showed the premises of the evolutions to be observed in the 2000s. The trajectories of these two towns, both geographically peripheral in their new state and intimately linked to each other, started diverging inexorably from the 1970s though. While the rulers in Abu Dhabi and Muscat were driven by similar political priorities in the decades following the independence (asserting their political power through the construction of a centralised state apparatus and a new national identity embodied by the paternalistic figure of the 'father of the nation'), the parts played by al-Ayn and al-Buraymi in these political constructions have been drastically different. Elites native of al-Ayn have retained crucial influence in Abu Dhabi, contrary to al-Buraymi's populations within the Omani regime. In addition to it, the highly centralised and authoritarian nature of the decision-making in both states has not allowed any latitude of action for institutional cross-border cooperation initiatives from local authorities and administrations.

\section{Al-Ayn and al-Buraymi: Contrasting roles in the nation-building project}

The oasis of al-Ayn/al-Buraymi, shared nowadays between the Emirate of Abu Dhabi and the Sultanate of Oman, has been a highly coveted zone since the eighteenth century, due not only to its abundant agriculture resources in a very infertile hinterland but also to its strategic location at the centre of the Eastern Arabian Peninsula, almost equidistant from Abu Dhabi, Dubai (on the Persian Gulf) and Sohar (on the Gulf of Oman). The oasis is described at the 
beginning of the $20^{\text {th }}$ century as 'verdant and fruitful. The soil though thin is fertile, and streams of running water abound on every side' ${ }^{24}$ By opposition to its hinterland populated by nomadic tribes, the society of the oasis was long composed of sedentary town dwellers (hadar), engaged in agriculture activities, and semi-nomad groups who used to settle in the oasis during the summer and to live nomadically during the winter, and who became sedentary cultivators in the second half of the $20^{\text {th }}$ century. The total population was estimated to amount to 5,500 inhabitants in $1915^{25}$ and to 25,000 in 1960 . Communications remained extremely difficult until the 1960s, as illustrated by the account of British traveller Wilfrid Thesiger in 1948, who reached the oasis from Abu Dhabi after a four-day camel ride. $^{26}$

Until the beginning of the $20^{\text {th }}$ century, political control over the main tribal confederations living in the oasis oscillated between the rulers of Abu Dhabi, Muscat and Saudi Arabia. At the beginning of the $19^{\text {th }}$ century, then ruler of Abu Dhabi Shakhbut Al Nahyan (r.1793-1816) built a fort there, reflecting the old personal connection of the ruling family of Abu Dhabi with the oasis. His grandson Zayed bin Khalifa (r.1855-1909) helped the Imam of Oman take control of the oasis from the Saudis in $1869^{27}$ and consolidated his control over some of the tribes by buying lands there. ${ }^{28}$

In 1922 and 1923, the British imposed treaties according to which no oil concession would be granted by local rulers except to somebody approved by the British government. Several agreements on oil exploration rights in al-Buraymi area were then signed but the Second World War put an end to these hopes. Prospecting started again in 1948, but Iraq Petroleum Company (IPC) soon realised that the Sultan of Oman did not have much control over the relevant territories, despite his bribing of local tribes. In 1949, King Abd al-Aziz of Saudi 
Arabia (r.1932-53) awarded a concession to the Arabian American Oil Company (Aramco) south of al-Buraymi; the company started exploration, highlighting a new British-American (IPC versus Aramco) tussle over oil-bearing areas. Aware that their area of influence was threatened by this oil alliance between United States and Saudi Arabia, the British created a military force in Abu Dhabi, the Trucial Oman Scouts. With exacerbation of tension over oil concessions, several tribal groups (especially the Bani Qitab, Naim and Bani Kaab) settled in the contested areas made use of the struggle for influence between Abu Dhabi, Muscat and Riyadh to hold on to their autonomy. The Saudis occupied al-Buraymi in August 1952 and appointed a governor who managed to secure the allegiance of many tribal leaders of the oasis. ${ }^{29} \mathrm{~A}$ temporary agreement was signed between the Saudis and the British in October 1952, to appeal to outside arbitration. However in October 1955 the British, 'fully convinced that they were going to lose the case ${ }^{,}{ }^{30}$ stopped the discussions unilaterally; the Trucial Oman Scouts recaptured al-Buraymi oasis at the end of the month. In 1959 and 1960, the Sultan of Oman and the ruler of Abu Dhabi signed agreements under the auspices of the British to delineate areas under respective authority. This clarification over territories of sovereignty was mainly intended to facilitate the awarding of concessions to British companies in area where boundaries had made no sense until then.

Future UAE President Zayed AI Nahyan himself was born in the oasis in 1918 and was the representative of the ruler of Abu Dhabi in the oasis from 1946 to 1966; this personal connection contributes to explain al-Ayn's special role in the new UAE state after the independence. By the mid-1960s already, the villages under Zayed's authority benefited from a hospital and a school staffed with Jordanian teachers - many years before the same facilities 
would be available in the Omani-controlled part of the oasis and in the town of Abu Dhabi itself. $^{31}$ Since 1971 the ruler's representative in al-Ayn has been Zayed's cousin's son Tahnoon Al Nahyan. A prominent businessman, ${ }^{32}$ he has held top decision-making positions at the emirate level, including deputy chairman of the Abu Dhabi Executive Council (Abu Dhabi's emirate-level cabinet) from 1977 to 2004 and board member of the Supreme Petroleum Council, the highest governing body of hydrocarbons activities in the emirate (1988-2004). Zayed's son and current UAE ruler Khalifa bin Zayed (r.2004-), who was his father's representative in al-Ayn (1966-1970), has been maintaining his principal family home in alAyn. $^{33}$

This political influence of al-Ayn connections does not stop at the Abu Dhabi ruling family. Beyond their own tribe, Zayed and his son Khalifa have heavily relied on tribes native from al-Ayn to fill sensitive civil and military positions - as the latter have been considered as the most reliable partners to strengthen the Al Nahyan grip on national power. This is the case for the Dhawahir tribe (in the army, in the Interior and in ruling family members' personal offices) ${ }^{34}$ and for the Bani Qitab (in the army and the police). ${ }^{35}$ Moreover Gervais explains that 'the lack of trust of some tribes vis-à-vis the ruler of Abu Dhabi [...] did not result in their exclusion from the circles of power. On the contrary, it was offset by the ruler's effort to increase these tribes' dependence on him, through repeated integration of its members in the state apparatus' ${ }^{36}$ As an illustration of this policy, the Bani Kaab, who long resisted domination from both the rulers of the Trucial Coast and the Sultan of Oman, were given key positions by Zayed after the independence ${ }^{37}$ in order to ensure their loyalty to the regime. 
From the independence, the oil rent has been used by Zayed Al Nahyan to develop local infrastructure and to exert a growing influence on the borderlands. The national university (UAE University), the first in the country, opened in al-Ayn in 1976. By the end of the 1970s a four-lane highway was connecting al-Ayn to the capital and in 1994 an international airport opened. In 1981, the first dairy farm in the UAE was created in al-Ayn, which has become one of the largest in the Middle East. A few years later, the first Coca-Cola bottling plant in the Middle East started to operate, and al-Ayn has been home of one of the world's largest date producers (Al Foah). In addition, two private universities (Al-Ayn University of Science and Technology and Abu Dhabi University's local branch) were established in the 2000s.

Al-Ayn has been trying to develop as a tourism and recreation hub too. As early as 1971 al-Ayn national museum, the first in the country, was opened. Three major shopping malls were established by the end of the 1990s. In 2011, the local cultural sites, constituted by 17 components, including prehistoric tombs and irrigation systems dating from the Iron Age, were registered on UNESCO's World Heritage List.

In 2009, an ambitious Plan Al-Ain $2030^{38}$ identified aviation and defence as key engines of the city's development, in addition to existing agro-business. The Nibras Al Ain Aerospace Park was started in 2010 and is intended to be an industrial platform for manufacturing and maintenance facilities and training and research institutions. The home of Etihad Airways' pilot training centre, it is expected to create 10,000 jobs by 2030. Plan Al-Ain 2030 estimated that the city population will reach one million by that year and includes a comprehensive redevelopment plan for the central district and the construction of a tram system, the second to open in the Gulf after Dubai in 2014. 
Obviously al-Buraymi has not held the same political role in Oman under Sultan Qaboos and the disparity of treatment between al-Ayn and al-Buraymi by their respective national authorities was to be seen soon. Until the early 1990s, the Sultanate was divided into two governorates (muhafadha) and nine regions (mintaqa), including the 'Jaw and al-Buraymi' one - which covered the UAE borderland. In 1991 the national territory was re-divided into five new regions and three new governorates. These new administrative entities were designed around regional capitals destined to become conveyor belts between Muscat and their respective hinterlands. The former Jaw and al-Buraymi region was merged into the Dhahira region. Ibri, instead of al-Buraymi, became the capital of the new entity. Was this absorption of al-Buraymi by the Dhahira region a way to endorse a fait accompli, i.e. the slow economic marginalisation of this borderland territory? Or was it a more political decision intended to re-assess alBuraymi's full belonging to the Omani nation, by tying it economically and administratively to the interior of Oman? In any case, as a result of this downgrading to just one provincial town in northern Oman among others, al-Buraymi remained a semi-rural provincial town well until the early 2000s, broadly neglected by the post-1970 centralised modernisation process. Beyond its fort and a souk, tourist resources have remained notably underdeveloped in al-Buraymi, as bluntly acknowledged by the latest edition of the Lonely Planet guide: 'It's fair to stay that there's not much reason to make a special visit other than if you're using the UAE border for Al-Ain and Abu Dhabi. ${ }^{39}$ With regard to education, two private higher education institutions (Buraymi University College and University of Buraymi) opened their doors (only in 2003 and 2010 respectively), and have not yet stood the test of time. Until the 2000 s, few measures addressing specifically borderland regions, and al-Buraymi in particular, had been implemented 
to avoid their increasing extraversion towards the UAE. The only noticeable action taken by the central government was the prevalence in cabinets of personalities originating from tribes of northern Oman. ${ }^{40}$ They were said to receive preferential treatment aimed at diverting them from the enticements of the UAE.

The contrast between the two cities after three decades of contiguous but separate development was summarised by Christopher Davidson: 'Throughout Zayed's reign as ruler of Abu Dhabi, an enormous amount of the emirate's wealth was channelled into Al-Ayn, transforming the city into a modern commercial hub, a booming agricultural center, and of course into the "garden of the Gulf," with many miles of beautiful parks and landscaped areas. In complete contrast, one can walk just a few hundred yards outside of Al-Ayn into the Omanicontrolled and comparatively undeveloped town of Buraimi and perhaps imagine what Al-Ayn would have looked like today if it had not received such munificence' ${ }^{41}$ Then it is no surprise that the UAE's symbolic, cultural and economic influence on northern Oman has only grown stronger from the 1970s. The UAE is the first economic partner of Oman, with $27 \%$ of its importations in value and $70 \%$ of its non-oil exports. It has been a geographical sales outlet for the Omani exporting companies, a source of supply for petty illicit dealing and private trade, and a place where many Omanis of all social conditions, especially from the northern regions, go to at weekends, either for fun or for commercial deals. More particularly, the lack of employment opportunities in northern Oman (other than in local branches of government and public sector administrations) explains why the job market in the UAE has remained attractive to many low-skilled Omani individuals. Omani nationals, many of them from border cities and regions, have been highly represented in the UAE Armed Forces until the beginning of the $21^{\text {st }}$ 
century. Joseph Kechichian estimates that more than 30,000 Omanis were already living and working in the UAE in the mid-1970s, $85 \%$ of whom serving in the military. ${ }^{42}$ This number has consistently increased until the early 2000s. Last but not least, for technical reasons (secondary school certificate marks too low to gain admission to Sultan Qaboos University), financial reasons (inability to pay the tuition fees in private Omani institutions), or personal ones (regular returns to Oman), 8,400 Omani students (of which $81 \%$ girls) were registered in UAE universities in 2011 (a substantial number in lesser ones, like 'Ajman), which represented approximately $56 \%$ of all Omani students abroad. ${ }^{43} \mathrm{~A}$ civil servant native from northern Oman highlights the underlying political issues: 'In [some towns], $80 \%$ of the population is dependent on the UAE; people are working on construction projects in [the UAE]. Local sheikhs are related to Sharjah and Dubai families, by marriage, family agreements or business. [The towns are] completely turned towards the UAE. ${ }^{44}$

As highlighted by Jean-Luc Piermay in his works on borders in Africa, 'the main characteristic of the border is that it creates differentials: differentials of prices, of revenues, of regulations, of supply networks, of modes of organisation, etc. [...] Local actors optimise these differentials. ${ }^{45}$ As such, the border generates new resources, and strategies of adaptation and accommodation have been taking place. By the end of the 1990s, al-Buraymi had become a dormitory town for al-Ayn. The number of al-Buraymi residents commuting every day to work in al-Ayn, and even to Dubai, was estimated at 40,000 by the mid-2000s. ${ }^{46}$ At the national level, rents and salaries have been much lower in Oman compared to the UAE, and the situation in the two border cities illustrates it, but at a more extreme level. House rents have been three to five times lower (and salaries two to three times lower) in al-Buraymi compared to al-Ayn. ${ }^{47}$ As 
a result of this differentials, a lot of expatriates, in addition to all cross-border Omani workers, were living in al-Buraymi but working in al-Ayn - either with a UAE working visa or with an Oman residence visa. More generally, al-Buraymi foreign residents have been used to cross the border for work, education ${ }^{48}$ and have fun in al-Ayn parks, malls and cinemas. On the other way round, al-Ayn inhabitants have gone to al-Buraymi to buy cheaper everyday goods, such as furniture and petrol, due to significantly lower prices in Oman compared to the UAE.

Similarly, the difference of regulations in the hiring of foreign domestic workers and in the issuance of working visas (both processes are allegedly much quicker in the UAE than in Oman) explains that recruitment agencies in al-Ayn and al-Buraymi have been specialising in a human trafficking economy, by bringing housemaids across the border from the UAE into Oman, instead of hiring them directly from the home country (Philippines, Sri Lanka and Indonesia). ${ }^{49}$

The contrast of trajectories between the two contiguous cities has been best illustrated in their demographic evolution (see table 1). While the total population of the oasis was estimated to approach 25,000 in 1960 , most probably equally distributed across the border, it is fair to assume that by 1970 the population of the UAE side had already surpassed its Omani counterpart. By 1993, when the first census was conducted in Oman, al-Ayn's urban population had quadrupled compared to 1975 and was four times higher than al-Buraymi's. The gap only increased during the following two decades, as al-Buraymi's population doubled between 1993 and 2016 while al-Ayn's population expanded by more than two times and a half. Al-Ayn is now five times bigger than its Omani counterpart. 
For long, this extraversion of its borderlands towards the UAE was probably not an issue for the Omani government, who considered that the massive number of Omanis employed and earning a living in the UAE helped alleviate the financial burden of developing peripheral regions of the sultanate. The beginning of the 2000s marked a dramatic turn in the UAE-Oman relations, which, as a logical consequence, directly impacted the relationship between the two contiguous cities of al-Ayn and al-Buraymi.

\section{The UAE and Oman turning their back to each other from the 2000s}

It is at the time when the two countries reached an agreement on the delineation of the border and that observers were considering that "both sides concluded that their destinies were inevitably and permanently tied, for better or worse ${ }^{\prime 50}$ that the question of the symbolic and physical separation from the (br)other came back to the fore. In January 2002, the UAE announced that work was underway to install a fence along the UAE-Oman border. ${ }^{51}$ In spring 2003, Oman introduced an exit toll on crossing the United Arab Emirates border (2 Omani Rials [OR] per light vehicle going abroad)..$^{52}$ By 2004, a 12 -foot high border fence with barbed wire was dividing al-Ayn/al-Buraymi oasis and border control on all vehicles and pedestrians were severely tightened by the UAE authorities. On the Omani side, al-Buraymi was transformed into a no man's land as no checkpoint has been present immediately over the border; checkpoints have been set $40 \mathrm{~km}$ inland, on roads from al-Buraymi to Muscat and Ibri in June 2004. NonGCC residents of al-Buraymi were restricted to this 40 -kilometre radius. ${ }^{53}$ 
Abu Dhabi's decision to erect a fence to materialise the separation with Oman, more than three decades after independence, was officially justified by UAE criticism towards Oman's policy on migration control. The UAE considered that Oman was not doing enough to fight illegal immigrants from Pakistan and Afghanistan passing through the Gulf of Oman and the Sultanate to find jobs in the UAE. As a matter of fact, a three-day coordinated crackdown was launched by the UAE and Omani authorities in July 2004 in al-Buraymi and in nearby villages, resulting in the arrest of 1,000 of illegal immigrants. ${ }^{54}$ However the militarisation of the border and the cooling of relations resonate with more structural political and economic challenges faced by these two young regimes.

\section{New challenges impacting the relation with the brother}

By the beginning of the $21^{\text {st }}$ century, both countries were started facing a series of domestic challenges calling into question the socio-political order established in the 1970s. In Oman, the regime's état de grâce was coming to an end. Given Oman's limited hydrocarbon resources compared to its neighbours, a long-term economic program called 'Oman 2020: Vision for Oman's Economy' was established in 1995 that promoted economic diversification and nationalisation policy for private sector jobs. However these policies had limited results, as illustrated by growing inequalities, endemic unemployment, and poverty, especially outside the capital. This sensitive social climate was already causing a revival of frustration and mutual prejudice, leading to a re-polarisation of society. This was taking place both in the socioeconomic field, through clientelism and favouritism, and on a more symbolic form through 
competitive bidding in declarations of Omanity along ethno-linguistic and tribal lines. These dynamics were a sign that growing sectors of society, in particular among the young generations, were already reluctant to guarantee the perpetuation of a system in which they were feeling excluded from political and economic decisions.

The UAE was not facing similar immediate economic challenges. However with Abu Dhabi being by far the largest contributor to the UAE federal budget, and its share of oil reserves representing $95 \%$ of the UAE's total, the questions surrounding the approaching end of the reign of Zayed Al Nahyan were becoming crucial. As explained by Christopher Davidson, the UAE regime's model of legitimacy was intimately linked to the person of the 'father of the nation' Zayed Al Nahyan, the figure embodying the UAE welfare state and the redistribution of money and wealth to the citizens and among the different emirates, and to him only: 'Few would doubt that Shaikh Khalifa [...] could ever hope to draw upon the same level of personal legitimacy from his subjects as his distinguished father. ${ }^{, 55}$

Among the other questions that the authorities were concerned with was the nationals/expatriates imbalance, and the alleged impact of demographics on the Emirati identity, culture and national security. On the occasion of a conference on national identity in April 2008 Dubai's Police Commander in Chief warned that the Emiratis being a minority in their own country could lead to the collapse of the regime: 'We are building towers but losing the Emirates' ${ }^{56}$ Thus, for Abu Dhabi, the questions of the succession of Zayed bin Sultan, the political and economic pre-eminence of Abu Dhabi on the federation and the UAE national identity were all interrelated - especially when dealing with the relation to the Omani neighbour and brother. 
2003 and 2004 were also marked by the political ascension of third son of Zayed, Mohammed. His appointment as Deputy Crown Prince of Abu Dhabi was followed by his nomination as the Deputy Supreme Commander of the UAE Armed Forces in January 2005, after the death of his father. Mohammed bin Zayed quickly started implementing a policy to replace Omanis serving in the federal security forces, out of the perception that such a presence could have adverse effects in case of UAE-Oman political tensions. The impact of this change of policy was felt immediately in Oman, as many low-skilled and unskilled Omanis who had been living in the UAE and sending remittances to their relatives who had stayed at home, returned to the country to compete for jobs with home Omani job-seekers on an already saturated job market.

\section{Physical demarcation with the (br)other}

In February 2005, Sultan Qaboos' first annual tour across the country since the death of Shaykh Zayed took place in the provinces bordering the UAE. This tour was the setting for long-awaited development projects, in the matters of housing, road infrastructures and social services. It marked a drastic change in the policy of the Omani government towards the border regions. Due to the growing economic extraversion of Northern Oman towards UAE development, the Sultan was worried about losing the allegiance of these regions breaking away in favour of Saudi Arabia in the 1950s and nowadays looking over the border with envy. Oman's 2006 budget and the Seventh Five-Year Plan (2006-2010) illustrated this re-evaluation of the border region: this area was to be 'accorded special attention by the Sultan,' as explained by Minister 
of National Economy Ahmed Makki. ${ }^{57}$ In addition to OR108 million (US\$281 million) specifically allocated in the annual budget, an additional OR50 million (US\$130 million) was put aside in the Five-Year Plan for public investment plans (transport infrastructure, schools, etc.) as well as tax concessions to the private sector to encourage industrial and tourism projects in these provinces.

In September 2006, in a new sudden unexpected change, non-GCC nationals holding Omani residence visas, suspected of working and/or living in the UAE, were no longer allowed to enter the UAE unless they purchase a 100 UAE Dirham (AED) entry visa. This measure, which had initially been implemented in some border checkpoints outside the cities, did not affect expatriates with a UAE residency living in al-Buraymi, who could move freely. ${ }^{58}$ In addition to it, it was decided that GCC nationals only could pass through the city centre's border point (alMadeef) while non-GCC nationals (even holding a UAE residence) were required to use another border point north of the cities (al-Hili). Again, the Omani authorities considered that these decisions were taken without prior notice and affecting badly business and economic situation in al-Buraymi. In retaliation, the Sultan of Oman issued a royal decree in October 2006 dissociating al-Buraymi from Dhahira province and establishing a new al-Buraymi governorate comprising three border provinces, and several ministers were urged to rush to al-Buraymi to announce new infrastructure investments. ${ }^{59}$ It is no surprise that these short-term belated decisions were received with scepticism in al-Buraymi. Its residents perceived them as coming too late to offset the effects of the Kafkaesque situation in which their city finds itself, since, due to the presence of the checkpoints $40 \mathrm{~km}$ inland since 2004, an expatriate holding an Omani tourist visa cannot enter al-Buraymi without having his visa cancelled. ${ }^{60}$ 
In summer 2008, the border point reserved to non-GCC nationals (al-Hili) was temporarily closed, requiring them to pass through a new one, some $20 \mathrm{~km}$ away south of the cities (Khatam al-Shakla). As nicely described by a local businessman, overnight al-Buraymi shops were 'no longer local' ${ }^{61}$ for al-Ayn residents, who represented the vast majority of customers of many shops in al-Buraymi but who suddenly had to drive $40 \mathrm{~km}$ to do some daily shopping. Moreover a new UAE visa rule was implemented. Until July 2008 people whose UAE visit visa had expired were able to take short trips to neighbouring countries such as Oman and Qatar to renew it. Under the new rules, the practice became no longer permissible for all but 33 exempt nationalities. Visitors from other countries were required to return to their home countries for at least a month before being issued another visa. Then thousands of people were stuck outside the country (many of them in al-Buraymi) after attempting visa runs, caught unawares by the new law. ${ }^{62}$ As a result of these various policies implemented by the UAE, the number of expatriates based in al-Buraymi dropped significantly during the second half of the 2000s (see table 1).

\section{The Arab Spring: Security first}

Tensions peaked at the end of 2010 when Omani security officials claimed that authorities had uncovered a spy ring 'affiliated to the state security service of the UAE targeting the regime in Oman', leading to the arrest of 20 Omani officials. ${ }^{63}$ The UAE denied the allegations but the crisis was considered serious enough by the other Gulf monarchies that mediation was conducted by the Emir of Kuwait in March 2011 to try and solve the dispute. 
This revelation came a few weeks before the Sultanate experienced its most widespread popular protests since the end of the Dhofar war, as part of the Arab uprisings. Major popular mobilisations took place in the northern town of Sohar, where two protesters died in February and April $2011 .{ }^{64}$ Demonstrations and rallies leading to clashes with the security forces were held in al-Buraymi too. Following the clearing of the peaceful gatherings by riot police, a creeping militarisation of the territory took place, as shown by the transformation of Sohar and al-Buraymi into fortified cities in April and May 2011, with the deployment of the army in town, and the drastic increase of police controls and check-points on roads to the UAE since then.

During all this troubled period, and more generally since the independence, there has been a complete absence of contacts and relations at local level for solving problems, let alone any attempt at establishing local channels of institutional cooperation. This has to do with the authoritarian and hyper-centralised nature of decision-making processes in both Muscat and Abu Dhabi, where all initiatives come from the central government. Far from pushing for some decentralisation, the creation of a governorate in al-Buraymi in 2006, where the governor is appointed by sultan's decree and acts under the strict supervision of the Minister of Interior, was clearly intended to re-assert central control on the border region. On the occasion of his visit to al-Buraymi in May 2008, the US Ambassador to Oman had the opportunity to experience the governor's total absence of latitude of action: 'Of interest is what was not discussed during the Ambassador's initial meeting with [...] the governor of Buraimi. In submitting the request for the appointment, the Ministry of Foreign Affairs agreed to schedule it on the condition that the Ambassador not raise any substantive issues with the governor. The meeting itself was devoid of genuine substance, an indication that the sheikh was following 
strict [Ministry of Foreign Affairs] orders to keep discussion to the weather and the immaculate condition of Buraimi's streets. ${ }^{65}$ In October 2011, a sultan's decree announced the establishment of municipal councils in all governorates. However, this attempt to show Qaboos's attentiveness to the population's aspirations for greater participation in decisionmaking had only very limited impact. Composed of members elected by universal suffrage for four-year renewable terms, as well as ex-officio members representing ministries, the municipal councils are chaired by the sultan-appointed governor. They have only advisory powers, and provide opinions and recommendations only on the development of municipal services in the governorate (infrastructure, health, local taxes, and so on). On the UAE side of the border, the ruler's representative in al-Ayn belongs to Al Nahyan's ruling family and Abu Dhabi inner circles of power, which explains that no intention of cross-border cooperation has ever been present among local authorities.

In October 2013, in a rare coordination move, the two countries decided to go a step further in making border-crossing more difficult by introducing a new border-crossing tax for expatriates. All non-GCC nationals would pay AED35 to enter the UAE and, if they have no residence visa in Oman, OR5 to enter al-Buraymi from Oman (there is no fee to leave the UAE and to enter Oman). This applies to expatriates with the UAE residency permits living in alBuraymi and working in al-Ayn and to expatriate students living in al-Buraymi and attending school in al-Ayn due to the lack of educational offer on the Omani side, who benefited until then from entry passes issued by Abu Dhabi authorities allowing unlimited crossing. ${ }^{66}$ In October 2015 the UAE tightened the rules further by requiring all citizens from countries like 
India, Pakistan and Philippines - regardless of their professional status and even if they have a residence visa for Oman - to apply for a visa to be able to travel to the UAE. ${ }^{67}$

These new regulations were obviously motivated by increasing security concerns in both capitals. In the aftermath of the Arab Spring, Muscat and Abu Dhabi presume that the other is a cause of political destabilisation - as a porous border is supposed to result in more smuggling and entry of illegal migrants on one side (from the UAE point of view) and in the proliferation of Islamist activism and/or spying networks (according to Oman). Since 2011, senior Omani officials and the national media have repeatedly accused protesters of being under foreign influence, in order to discredit them and their demands. An illustration of this was the sentencing of a Salafi Parliament member from Liwa (North Batina governorate) in 2014 to three years in jail on charges of illegal gathering and undermining the status and prestige of the state. Concomitantly, four of his supporters (businessmen and civil servants) from al-Buraymi were arrested and held for several months. ${ }^{68}$ Omani intelligence and internal security made unambiguous references to the support that these Salafi networks in Oman could have benefited from UAE individuals. In addition to these security concerns, these sealing measures intend to increase competition between the two cities, by forcing them to turn their back to each other and to develop independently (and at the expense of) the other.

\section{Conclusion}

Since the 1970s, border cities of al-Ayn and al-Buraymi have been following divergent, and by many aspects, opposed trajectories - emulating the way how the United Arab Emirates and 
Oman have grown separately. Despite the shared history and the undisputable 'feeling of belonging together ${ }^{69}$ that has presided for long over the relations among inhabitants of the two cities, the imperative for both regimes to turn their back to each other, for legitimacy and security purposes, have translated in al-Ayn/al-Buraymi in a complete absence of local crossborder co-operation and in growing asymmetries - in size, in economic wealth and attractiveness and in political influence on the national arena. The erection of the fence across the conurbation in the 2000s and the materialisation of the separation from the br(other) that went with it have played a key role in increasing this - local and national - gap. Even more than allowing the UAE (and al-Ayn) to project its power over Oman (and al-Buraymi), the physical demarcation from the neighbour, and the extent of devices and measures mobilised for it, has to be understood as part of the strategies of legitimation used by the ruling family of Abu Dhabi for the last decade. For a small state like the UAE that has branded itself as the epitomy of a globalised country, the fenced wall with Oman has played a critical role in justifying its existence as a nation - after the demise of the 'father of the nation' sheikh Zayed - and as a federal state - distinct from its Omani brother. This question has been crucial for the Omani regime too, considering the structural economic challenges faced by the Sultanate since the beginning of the $21^{\text {st }}$ century, the increasing dependency of many provinces of northern Oman towards the UAE and the political consequences that ensue, of which the protests taking place during the Arab Spring have been one illustration among others. No wonder therefore that these issues have crystallised in the peripheral border cities of al-Ayn and al-Buraymi, where the questions of political allegiance and belonging to the national community have been critical since the mid- $20^{\text {th }}$ century. 
${ }^{1}$ Isra' and Miraj is an Islamic feast commemorating Muhammad's journey from Mecca to Jerusalem followed by his ascension to heaven where he received God's instructions before coming back to Earth.

2 J. Buursink, 'The Binational Reality of Border-Crossing Cities', GeoJournal 54/1 (2001) pp.7-8.

${ }^{3}$ Y. Gradus, 'Is Eilat-Aqaba a Bi-National City? Can Economic Opportunities Overcome the Barriers of Politics and Psychology?,' GeoJournal 54/1 (2001) pp. 85-99.

${ }^{4}$ H. Eskelinen and P. Jukarainen, 'New Crossings at Different Borders: Finland,' Journal of Borderland Studies 15/1 (2000) pp.255-79; T. Lundén and D. Zalamans, 'Local Co-operation, Ethnic Diversity and State Territoriality - the Case of Haparanda and Tornio on the SwedenFinland Border,' GeoJournal 54/1 (2001) pp. 33-42.

${ }^{5}$ N. Ryzhova, 'Informal Economy of Translocations. The Case of the Twin City of BlagoveshenskHeihe', Inner Asia 10/2 (Dec. 2008) pp.323-51; E. Mikhailova, 'Border Tourism on the RussianChinese Border', Journal of Siberian Federal University. Humanities \& Social Sciences 3 (2015) pp. 437-51.

${ }^{6}$ J. Durrschmidt, 'So Near Yet So Far: Blocked Networks, Global Links and Multiple Exclusion in the German-Polish Borderlands', Global Networks 6/3 (July 2006) pp.245-263.

${ }^{7}$ Buursink (note 2) p.8.

8 Ibid., p.17.

${ }^{9}$ Mikhailova (note 5) p.438. 
${ }^{10}$ Buursink (note 2) p.15 explains that 'an adjacent location evidently is a necessary condition, but not a sufficient condition [...] To call two adjacent cities 'twins' they should also be of about the same age, appearance and size. Moreover, the 'twin' metaphor suggests a cordial relation which makes real twins inseparable, likeminded and acting co-operatively'.

${ }^{11}$ See J. B. Kelly, 'The Buraimi Oasis Dispute,' International Affairs 32/3 (July 1956) pp 318-26;

J. C. Wilkinson, Arabia's Frontiers: The Story of Britain's Boundary Drawing in the Desert (London: I.B. Tauris 1991); J. B. Kelly, 'Arabian Frontiers and Anglo-American Relations,' Government and Opposition 27/3 (Summer 1992) pp. 369-84; T. T. Petersen, 'Anglo-American Rivalry in the Middle East: The Struggle for the Buraimi Oasis, 1952-1957,' International History Review 14/1 (Feb. 1992) pp.71-91; R. Schofield, 'The Crystallisation of a Complex Territorial Dispute: Britain and the Saudi-Abu Dhabi Borderland, 1966-71', Journal of Arabian Studies 1/1 (2011) pp.27-51; M. Q. Morton, Buraimi. The Struggle for Power, Influence and Oil in Arabia (London: I. B. Tauris 2013).

${ }^{12}$ R. S. Zahlan, The Making of the Modern Gulf States: Kuwait, Bahrain, Qatar, the United Arab Emirates and Oman (London: Unwyn Hyman 1989) pp. 13-14.

${ }^{13}$ A. Takriti, Monsoon Revolution. Republicans, Sultans, and Empires in Oman, 1965-1976

(Oxford: Oxford University Press 2013) p.153.

${ }^{14}$ Ibid., pp.285-6.

${ }^{15}$ Indeed, two of the historical names of the contemporary United Arab Emirates are 'the Coast of Oman' (in Arabic, sahl Uman) and 'Trucial Oman' - in reference to the 1853 Perpetual Maritime Truce treaty enforced by the United Kingdom to the local sheikhs. Moreover, under 
British rule, up to the 1960s, travel documents identified inhabitants of the current UAE as

Omanis.

${ }^{16}$ Quoted by J. Kechichian, Oman and the World: the Emergence of an Independent Foreign

Policy (Santa Monica: Rand 1995) p.80.

${ }^{17}$ Takriti (note 13) pp.165 and 300.

${ }^{18}$ R. Schofield (note 11) p.27. However Takriti (note 13) mentions that by the end of 1974 'the Saudis were still indicating interest in the Buraimi villages' (p.286).

${ }^{19}$ F. al-Sayegh, 'The UAE and Oman: Opportunities and Challenges in the Twentieth-First

Century', Middle East Policy 9/3 (Sep. 2002) p.132.

${ }^{20}$ C. Allen and L. Rigsbee, Oman under Qaboos: From Coup to Constitution, 1970-1996 (London:

Frank Cass 2000) p. 195.

${ }^{21}$ Personal interview, Muscat, 31 May 2003.

${ }^{22}$ Quoted by F. al-Sayegh (note 19) p. 134.

23 'Zayed Pays Rich Tribute to Qaboos,' Gulf News (21 July 2002).

${ }^{24}$ J. G. Lorimer (ed.), Gazetteer of the Persian Gulf, 'Oman, and Central Arabia (Gerrards Cross: Archives Editions 1986 (1st ed. 1915)), vol.5, p.263.

${ }^{25}$ Ibid., p. 260.

${ }^{26}$ W. Thesiger, Arabian Sands (London: Longmans, 1959).

27 R. Landen, Oman since 1856: Disruptive Modernization in a Traditional Arab Society (Princeton: Princeton University Press 1967) pp. 139-40.

${ }^{28}$ Lorimer (note 24) pp.261-4. 
${ }^{29}$ V. Gervais, 'Du pétrole à l'armée. Les stratégies de construction de l'état aux Emirats Arabes Unis,' Etudes de l'IRSEM 8 (2011) pp.82-4.

${ }^{30}$ Takriti (note 13) p.22.

${ }^{31}$ C. M. Davidson, Abu Dhabi. Oil and Beyond (London: Hurst 2009) pp.46-7.

32 “Abu Dhabi's Nexus of Economic Power, Part II: The Abu Dhabi Executive Council," Wikileaks Cable from US Embassy in Abu Dhabi (03ABUDHABI3208_a), 9 July, 2003.

${ }^{33}$ C. M. Davidson, 'After Shaikh Zayed: The Politics of Succession in Abu Dhabi and the UAE,' Middle East Policy 13/1 (Spring 2006) p.52.

${ }^{34}$ Van der Meulen explains that 'the domination of the Abu Dhabi military by the Bani Yas and Dhawahir tribes is almost total' (in The Role of Tribal and Kinship Ties in the United Arab Emirates, PhD (Medford: Tufts University 1997) pp.156ff.). Among a few examples, Mohammed bin Said al-Badi (a lineage of the Dhawahir tribe) was the UAE Defence Forces' chief of staff (1982-1992) then UAE Minister of Interior (1992-2004), succeeding another tribe member, Hamouda bin Ali al-Dhaheri. Similarly the Ministry of Justice has been held by members of the Dhawahir tribe since 1997.

${ }^{35}$ Fatima bint Mubarak, the third wife of Zayed, who is the mother of current Crown Prince of Abu Dhabi and Deputy Supreme Commander of the UAE Armed Forces Mohammed bin Zayed, is from the Bani Qitab tribe.

${ }^{36}$ Gervais (note 29) pp.107-9.

${ }^{37}$ The position of deputy chief of staff of the UAE Armed Forces was held by Ubayd bin Mohammed al-Kaabi at the end of the 1990s, then by Mohammed bin Hilal al-Kaabi (2005- 
2008) and then by Ali bin Mohammed al-Kaabi at the end of the 2000s, who was previously Commander of the UAE Land Forces.

${ }^{38}<$ https://www.ecouncil.ae/PublicationsEn/plan-abu-dhabi-full-version-EN.pdf $>$, accessed 15 Nov. 2017.

${ }^{39}$ Oman, UAE and the Arabian Peninsula (London: Lonely Planet 2013, $4^{\text {th }}$ ed.) p.171.

${ }^{40}$ J. E. Peterson, 'The Emergence of Post-Traditional Oman', Durham Middle East Papers 78 (2004) p.10.

${ }^{41}$ Davidson, 'After Shaikh Zayed' (note 33) pp.51-2.

42 J. Kechichian (note 16) p.78.

${ }^{43}$ Sultanate of Oman, Statistical Year Book 2012 (Muscat: National Centre for Statistics and Information 2013) tables 42-19, 43-19, 44-19 and 45-19.

${ }^{44}$ Personal interview, 14 February 2005.

45 J.-L. Piermay, 'Nouvelles frontières,' Outre-Terre 2/11 (2005), pp.63-4.

${ }^{46}$ A. Kazmi, 'Expatriates Get Separate Border Crossing at Al Ain,' Gulf News (14 June 2008).

${ }^{47}$ In 2008, the average annual rent for a three-bedroom villa in al-Buraymi was UAE Dirhams (AED) 12,000 [US\$3,200], compared to AED 70,000 [US\$ 19,000] in al-Ayn. In 2013, annual rent for a two-bedroom flat amounted to AED 12,000 in al-Buraymi compared to AED 70,000 in alAyn.

${ }^{48}$ There was no Indian school in al-Buraymi until 2008. Foreign children are not allowed to register in Omani public schools. On the contrary, apart with special permission, young Omanis cannot frequent community schools which group the expatriates' children according to their nationality. 
49 "Omanis Hiring Maids from the UAE: Probably Legal, but Problematic," Wikileaks Cable from US Embassy in Muscat (07MUSCAT206_a), 3 March 2007.

${ }^{50}$ Al-Sayegh (note 19) p.136.

${ }^{51}$ E. Abdullah, 'Fencing of UAE-Oman Border Starts,' Gulf News (17 Jan. 2002).

521 Omani Rial = 9.5 UAE Dirham = 2.6 US\$. Heavy vehicles over seven tonnes are charged OR8. An annual fee of OR12 is charged for government vehicles, cars carrying students studying in the UAE and those who cross the border every day.

${ }^{53}$ A. Kazmi, 'Tighter Curbs in Place at Al Ain-Buraimi Border,' Gulf News (29 June 2004).

${ }^{54}$ A. Kazmi, 'Hundreds of Expats Held in Buraimi Security Operation,' Gulf News (28 July 2004). The emirate of Abu Dhabi even claimed that a cell affiliated to al-Qaida planning to operate attacks in the UAE from al-Buraymi was unveiled.

${ }^{55}$ C. M. Davidson, The United Arab Emirates. A Study in Survival (Boulder: Lynne Rienner 2005) p.73.

${ }^{56}$ W. Keyrouz, 'Emiratis Fear Being a Minority in their Own Land,' Middle East Online (21 April 2008).

${ }^{57}$ S. Vaidya, 'Government Stops Collecting Tolls at Two Border Checkpoints,' Gulf News (2 Oct. 2006).

${ }^{58}$ S. Salama, 'Expats Charged Entry Fee at Oman-UAE Border,' Gulf News (29 Sep. 2006). On the contrary, residents in the UAE were still allowed to enter al-Buraymi as there was no checkpoint on the Omani side.

59 'New projects for Buraimi and Mahdha,' Gulf News (10 Oct. 2006).

${ }^{60}$ F. al-Ghadani, 'Expat Tourist Visa Plan for Buraimi,' Times of Oman (8 Feb. 2016). 
${ }^{61}$ L. Lancaster, 'Omani Town Laments Crossing Closure,' The National (14 July 2008)

${ }^{62}$ H. Dajani, 'Al Ain Border Crossing to Close,' The National (6 June 2008).

${ }^{63}$ S. Kerr, 'Oman Breaks Up UAE 'Spy Ring', The Financial Times (30 Jan. 2011).

${ }^{64}$ M. Valeri, 'The Suhar Paradox. Social and Political Mobilisations in the Sultanate of Oman since 2011,' Arabian Humanities 4 (2015). <https://cy.revues.org/2828>, accessed 15 Nov. 2017.

65 'Looking for Economic Growth in Oman's Interior,' Wikileaks Cable from US Embassy in Muscat (08MUSCAT359_a), 14 May 2008.

66 'Expats Will Have to Cough Up Dh35 for Stamping of Visas at Hili Post,' Times of Oman (27 Oct. 2013).

${ }^{67}$ R. K. 'UAE Visa Rule to Hit Million-Plus Expats in Oman,' Times of Oman (12 Oct. 2015).

68 In July 2014, it was estimated that 200 Omanis, mainly native from northern Oman, including al-Buraymi, had joined Sunni military groups in Syria. See T. al-Balushi, “Umaniyun Yuqatilun fi Suria" (Omanis Fighting in Syria) al-Balad (20 July 2014); < http://avb.soman.net/showthread.php?t=2198561>, accessed 15 Nov. 2017.

${ }^{69}$ M. Weber, Economy and Society: An Outline of Interpretative Sociology (New York: Bedminster Press 1968). 